\title{
The role of radiation treatment in the management of inflammatory musculoskeletal conditions: a revisit
}

\author{
Abbas A. Abdus-Salam ${ }^{1}$, Adeniyi Adedayo Olabumuyi ${ }^{2}$, Mutiu Alani Jimoh', Sharif Adeniyi Folorunso², \\ Ajibike Ayomide Orekoya ${ }^{2}$ \\ ${ }^{1}$ Department of Radiation Oncology, University of Ibadan, Ibadan, Nigeria \\ ${ }^{2}$ Department of Radiation Oncology, University College Hospital, Ibadan, Nigeria
}

Received: March 31, 2020

Revised: June 2, 2020

Accepted: June 3, 2020

Correspondence:

Adeniyi Adedayo Olabumuyi

Department of Radiation Oncology,

University College Hospital, Ibadan,

Nigeria

Tel: +234-808-111-3888

E-mail: niyi.oogaa@gmail.com

ORCID:

https://orcid.org/0000-0003-4428-7579
Inflammatory musculoskeletal conditions are a common group of diseases among the elderly, worldwide. They are characterized by articular degenerative changes accompanied with often debilitating pain. Treatments often involve life-long analgesic therapy or joint replacement in extreme cases. The aim of this current review is to look at the role of radiation treatment with the hope of further study into the effectiveness of radiation treatment in reducing pain, eliminate or reduce the need for lifelong analgesic therapy and thereby avoiding the analgesics' side effects. Extensive literature search was done on PubMed and other available data base and the findings are presented and discussed. Literature showed that many countries in Europe, especially Germany use radiation routinely for the treatment of many degenerative disorders including osteoarthritis with good results and few side effects. A pilot study is therefore recommended with a view to establish the effectiveness or otherwise of this treatment method in patients.

Keywords: Osteoarthritis, Joint diseases, Radiotherapy dosage, Radiobiology

\section{Introduction}

The inflammatory musculoskeletal conditions are a large group of disorders composed mainly of arthritis. The term arthritis in itself does not refer to a single disease condition, similarly the types of arthritis such as osteoarthritis (OA) have various subtypes.

In 2017, the Centers for Disease Control and Prevention (CDC) reported the prevalence of arthritis in the United States was 23\% with over 54 million people having the disease. In addition, over $60 \%$ of the people in the United States with arthritis are in the working age group (18-64 years) [1]. In Canada, arthritis is the 2nd and $3 r d$ most common condition in women and men respectively, affecting over 4.2 million people which accounts for $16 \%$ of the population 15 years and older [2]. Similar to the data form the United States, arthritis also significantly affects the working age group in Canada with nearly 3 in 5 people with arthritis in the country aged between 15 and 64 years [2].
Disabilities as a result of musculoskeletal disorders increased by 45\% from 1990 to 2010. Furthermore, OA is listed by the World Health Organization as the fastest increasing major health condition and ranked as the 2 nd leading cause of disability [3]. OA is the underlying cause for more than $90 \%$ of the increasing number of total hip or knee joint replacement operations worldwide [4].

Studies from Africa show the prevalence of OA in South Africa is over 29.5\% while that of Nigeria is 0.4\% [5]. The Community Oriented Program for Control of Rheumatic Diseases (COPCORD) studies in Asia show the prevalence of $\mathrm{OA}$ is as high as 34\% among people in the 60-64 years age bracket [6]. In the United States, the prevalence of OA increased from 6.6\% in 1999 to $14.3 \%$ in 2014 [7]. However, in the same time-period, in the United States, the prevalence of rheumatoid arthritis (RA) reduced from 5.9\% to 3.8\% [7].

Rheumatoid arthritis is the 2nd highest attributable disease to global disability [8]. It has a two-fold morbidity among women compared to men [9]. And it has been estimated that China had

Copyright@ 2020 The Korean Society for Radiation Oncology

This is an Open Access article distributed under the terms of the Creative Commons Attribution Non-Commercial License (http://creativecommons.org/licenses/by-nc/4.0/) which permits unrestricted non-commercial use, distribution, and reproduction in any medium, provided the original work is properly cited. 
over 5 million people diagnosed with rheumatoid arthritis by 2013 [10]. In Northern Europe and North America, the prevalence of RA is estimated to be $0.5 \%-1 \%[11-14]$. The prevalence of RA in the Middle East and North Africa region is among the lowest at $0.16 \%$ [9], while in South Africa it is 2.54\% [5].

lonizing radiation has been employed in treating malignant disease conditions for the last few decades with great success and outstanding improvement in the overall outcome of cancer care. lonizing radiation has also been employed for the treatment of some benign conditions including keloids, recurrent pleomorphic adenoma, Graves' orbitopathy, giant cell tumors of the bone, aneurysmal bone cysts and benign CNS tumors [15]. However, the role of radiation in the treatment of benign tumors is not as pronounced and well established as in its use for malignant conditions.

There is worldwide acceptance of the use of ionizing radiation in managing the aforementioned benign disease conditions. However, ionizing radiation is not a widely used treatment option in managing painful inflammatory/degenerative skeletal disease conditions [16]. The only part of the world where this is routinely done is in Central Europe, particularly Germany, Austria and Switzerland, and to a lesser degree in some parts of Eastern Europe [17].

Historically, there have been accounts of treating arthroses and arthritis with ionizing radiation. As early as 1952, Hill and Windeyer [18] reported on the utility of X-ray irradiation in treating $O A$ and ankylosing spondylitis. In the same article they mentioned the fact that the earliest published report on the benefit of ionizing radiation in cases of people suffering from joint diseases was by Sokoloff in 1897. In addition, Hall and Windeyer [18] also mentioned the fact that Anders et al. [19] in 1906 were the first to use the analgesic effects of $X$-rays to treat arthritis.

After the 1950's, radiation therapy for these conditions went into the history books for fear of secondary malignancies coupled with a lack of understanding of the mechanisms involved in radiation treatment for benign conditions $[17,20,21]$. However, over the years, the fields of radiobiology and radiation physics have evolved and improved. Therefore, it is becoming apparent that the use of radiation therapy in treating inflammatory/degenerative skeletal conditions was prematurely abandoned. This may have been due to poor understanding of the effects and mechanisms of the therapy. Muscoplat et al. [20] in their letter to the editor of the International Journal Of Radiation Oncology, Biology and Physics on radiation therapy for inflammatory arthritis concluded "There is a disconnect in medicine, whereby new therapies are enthusiastically adopted (e.g., biologic therapy for ankylosing spondylitis), even if risky, whereas old therapies, once abandoned, are overlooked even if the therapy was effective and the technology has been extensively improved (e.g., megavoltage radiation therapy). Radiation therapy is an "old therapy"; old therapies traditionally do not get studied by "modern" clinicians. In this instance, we may be missing an important and useful treatment. We would welcome a discussion of these topics to shed further light on mechanisms of disease, risk of therapies (and especially radiation therapy), and potential clinical studies that may help revive (if appropriate) an "old therapy" for patients with resistant spondyloarthropathy" [20].

The successful accounts of and extensive use of radiation for benign conditions in countries like Germany serve as reason to take a second look into this treatment modality, especially in low and middle income countries (LMICs) where the one-off cost model that may emerge may provide an incentive as opposed to the lifelong medication that arthritis often requires. It is noted that $8 \%-$ $10 \%$ of radiotherapy procedures in Germany are for benign disorders, and $70 \%$ of these indications are for painful disorders of the locomotor system [22]. Over 9,000 patients with $O A$ are treated with low dose radiotherapy every year, in order to relieve pain [23].

\section{Radiobiology}

The mechanisms by which ionizing radiation result in a therapeutic effect in benign diseases have been hypothetically classified as can be found in the review article by Trott and Kamprad [21]. These are as follows:

(1) Anti-proliferative radiation effects: This is responsible for the utility of radiotherapy in treating keloids, Dupuytren's contractures, fibromas or prevention of heterotopic ossification. Doses are generally 10 Gy or higher.

(2) Immunomodulatory radiation effects: This is responsible for the local suppression of autoimmune disorders such as endocrine orbitopathy. Optimal doses are also greater than $10 \mathrm{~Gy}$.

(3) Anti-inflammatory radiation effects: This is responsible for the analgesic effect of radiotherapy in inflammatory musculoskeletal conditions such as osteoarthritis, ankylosing spondylitis, periarthritis humeroscapularis or epicondylitis humeri. Total doses of 2-6 Gy are given in fractions of 0.5 Gy (though there are clinical evidences proving 1 Gy per fraction is as efficacious) $[16,24,25]$.

(4) Functional radiation effects: An ill-defined group assumed to effect through modulating responses of the autonomic nervous system or by interfering with gene activation. Optimal doses are usually less than $2 \mathrm{~Gy}$.

The cellular effects of radiation applicable in treatment of degenerative/inflammatory skeletal disorders have been noted by in vitro models and animal studies. They include:

(1) Modulation of endothelial cells: Endothelial cells play a large role in inflammation. Once activated, they secrete cytokines and 
recruit inflammatory leucocyte and also allow transendothelial migration of leucocytes. In vitro and in vivo studies have proven an increase in the expression of intercellular adhesion molecule 1 (ICAM-1) in endothelial cells upon exposure to ionizing radiation doses. This is noted to be linearly dose-dependent and peaking at doses between 4-10 Gy [21]. In addition, E-selectin-endothelial-leukocyte adhesion molecule 1 (ELAM-1)-secretion by endothelial cells is even more radiosensitive, with its messenger ribonucleic acid (mRNA) expression increasing within 2 hours of exposure to doses as low as $0.5 \mathrm{~Gy}$. However, this involves activation by nuclear factor kappa-light-chain-enhancer of activated $B$ cells (NFKB) [21]. On the other hand, for benign diseases, endothelial cells existing in inflammatory condition are in a different cellular condition and thus respond differently. Experiments have demonstrated a reduced adhesion of leukocytes onto activated endothelial cells upon irradiation of low doses between $0.3-1 \mathrm{~Gy}[21,26]$. This might be through the reduction in E-selectin expression in endothelial cells noted by Maggiorella (as cited in Trott and Kamprad [21]), upon exposure to low dose radiotherapy [21]. In addition, these effects have been observed to functionally coincide with nonlinear expression of the anti-inflammatory cytokine transforming growth factor $\beta$ (TGF- $\beta$ ) [27-29].

(2) Modulation of leucocytes: Irradiation of peripheral blood mononuclear cells (PBMC) and polymorphonuclear cells (PMNC) result in a discontinuous increase in apoptosis which reaches its peak at doses of 0.3-0.7 Gy. This coupled with enhanced proteolytic cleavage of L-selectin on apoptotic PBMC and the effect of low dose radiation (LDRT) on endothelial cells stated above reduces the number and recruitment of inflammatory cells. Furthermore, PMNC irradiated with doses below 1 Gy have been noted to have reduced secretion of chemotactic cytokine chemokine ligand 20 (CCL20) and modulated mitogen-activated protein (MAP) kinases and protein kinase B [27-29]. In addition, following LDRT of activated macrophages there is reduced expression of inducible nitric oxide (NO) synthase which is responsible for the synthesizing of NO. There is also reduced release of reactive oxygen species and reduced production of superoxide, reduced secretion of pro-inflammatory cytokine interleukin 1 and increased secretion of TGF- $\beta 1$ by pre stimulated macrophages $[27,30]$. These effects all contribute to an anti-inflammatory cytokine microenvironment for macrophages [27].

Calabrese et al. [31] in their study determining the optimal dose for radiotherapy of human inflammatory disease conditions noted that ionizing radiation elicits a pleiotropic effect in macrophages with two distinct phenotypes upon radiation depending on the dose. $A$ pro-oxidative $M 1$ phenotype results with X-rays of dose in the range used for treating malignancies. However, macrophages ex- posed to low dose radiotherapy with dose per fraction $<1$ Gy are polarized to the M2 phenotype which are anti-inflammatory.

\section{Animal Models}

These anti-inflammatory effects of LDRT were also corroborated by in vivo studies. Von Pannewitz [32] as reported in the review article by Arenas et al. [29] noted an improvement of clinical symptoms and reduction of synovial fluid and proliferation of synovial cells in rabbits knee arthritis once irradiated with 1 Gy of ionizing radiation. Similarly, another model using rats knee arthritis noted significantly reduced bone loss, cartilage degradation and joint swelling when irradiated with $4 \mathrm{~Gy}$ in 4 daily fractions of $1 \mathrm{~Gy}$ compared to significantly increased bone loss when exposed to 5 Gy single fraction of irradiation [33]. A few animal studies also had histological evaluation done on the animals after exposure to low dose radiotherapy and they showed reduced histological evidence of inflammation [34-36]. Hildebrandt et al. [37] induced adjuvant arthritis in rats to model rheumatoid arthritis by intradermally injecting heat inactivated Mycobacterium tuberculosis in paraffin oil into the base of the tail of rats. The study revealed LDRT ( 5 Gy in 5 fractions and 2.5 Gy in 5 fractions) resulted in statistically reduced arthritis score and hind paw volume. However, the histopathology revealed a significantly reduced joint destruction but non-significant change in inflammatory infiltrate of the hind paw. A review of animal studies [21] indicate LDRT to be more pronounced in degenerative arthritis than rheumatoid arthritis.

\section{Indication/Results and Outcomes}

There are contemporary reports of LDRT of benign inflammatory/ degenerative skeletal conditions (Table 1). Hautmann et al. [24] reported on their prospective trial in which 20 osteoarthritic knees associated with Baker's cyst were irradiated. They noted LDRT (3 Gy in 6 fractions at 0.5 Gy per fraction or 6 Gy in 6 fractions at 1 Gy per fraction or a single dose of $1 \mathrm{~Gy}$ ) improved (pain) numeric rating score (NRS), the Western Ontario and McMaster Universities Osteoarthritis Index (WOMAC) and the objective parts of the Knees Society Score significantly at short-term follow-up (6-12 weeks post-treatment) compared to baseline values. The volume of the Bakers cyst also reduced significantly $(p=0.002)$ at short-term follow-up compared to baseline volume. In addition, there was a persistence in the significant effect of LDRT pertaining to NRS, Knee Society Score, WOMAC score and cyst volume at longer term follow-up (9-12 months).

In another study on a subtype of $O A$, thumb carpometacarpal osteoarthritis (rhizarthrosis), Kaltenborn et al. [38] analyzed 84 pa- 
tients with 101 joints. The patients were treated with 6 Gy in 6 fractions at $1 \mathrm{~Gy}$ per fraction over 3 weeks using a 6-MV linear accelerator (LINAC). Multivariate logistic regression indicated remission induction was significantly associated with a larger field size (lager than $6 \mathrm{~cm} \times 4 \mathrm{~cm}$ ), and negatively associated with initial pain increase during radiotherapy [38].

The meta-analysis by Minten et al. [16] indicated there was insufficient evidence for a positive effect of LDRT in treating OA but, this was due to the absence of high-quality studies. However, their conclusion from the articles they studied was that LDRT decreased pain in 13\%-90\% of patients in the short term, while a long-term analgesic effect was observed in 44\%-87\% of patients. The meta-analysis also concluded that $29 \%-80 \%$ of the patients functioning improved on LDRT. However, no study with sufficient quality was retrieved. The authors thus advised a well-designed sham-controlled blinded randomized trial using validated outcome measures.

In a study on a total of 141 patients treated from 1983-2004 with LDRT (83\% received 6 Gy in 6 fractions at 1 Gy per fractions, the others received a total of 4-6 Gy) for periarthritis of the shoulder by Niewald et al. [17], 56\% of patients reported pain relief and improvement of mobility. On follow-up assessments at a median of 4.5 months, $69 \%$ of the patients reported pain relief, while $89 \%$ of patients reported improvement of motility. At a median of 3.9 years post-treatment $73 \%$ of patients reported both pain relief and motility improvement. The only side effect noted in one patient was a mild redness of the skin after radiotherapy. There were 7 patients who had swelling to start with. Three of these patients noticed an improvement immediately after radiotherapy, while 5 patients noticed this improvement at a median of 4.5 months thereafter [17].

In a prospective study by Micke et al. [22], 703 patients were treated for calcaneodynia, achillodynia, painful gonarthrosis, bursitis trochanterica, and painful shoulder syndrome with LDRT (6 Gy in 0.5-1 Gy per fractions). Baseline pain as assessed by visual analogue score (VAS) and pain relief according to the four scale "Von Pannewitz" (VPS) [32] were determined. These were also assessed immediately post LDRT. They also assessed the long-term effect of the treatment by systemic telephone survey in which the VPS was used to know which patients had a good long-term response. Their results showed that the median VAS scores immediately after treatment compared to before treatment was significantly lower in all categories of diseases and in all the patients ( $p<0.001)$. Comparing the proportion of patients tagged as good response by VPS on completion of LDRT to those with good response on long-term follow-up indicated all disease categories except for those with painful gonarthrosis had a higher proportion with good response to treatment on long-term follow-up compared to immediately after completing radiotherapy. The authors concluded the enthesopa- thies were more likely to achieve complete remissions with LDRT compared to gonarthrosis because gonarthrosis are due to pathologically irreversible processes in which bony and cartilaginous destructions occur. These cannot be reversed by radiotherapy. However, LDRT can still be of utility in relieving the accompanying inflammation and pain in the acute setting. And no side effects were observed $[22,25,32]$.

Literature [39] indicates a lack of efficacy in the use of ionizing radiation for treating rheumatoid arthritis. The authors conducted a randomized, controlled, double blind study in which one of the patients' joints was treated with X-rays from a LINAC (20 Gy in 10 fractions over 2 weeks) and another joint was treated by sham radiation. There was no significant change noted in the scores for tenderness, swelling, pain or disease activity and the study was stopped for ethical reasons. However, with regard to the radiobiology of $X$ irradiation of benign inflammatory/degenerative musculoskeletal condition, the dose irradiated in this study was too high. This might be the reason why no effect was observed. Notwithstanding, as was earlier noted the anti-inflammatory effect of LDRT on rheumatoid arthritis is not as pronounced as on degenerative arthritis [21]. The forms of radiation therapy applicable in rheumatoid arthritis include radiation synovectomy through intra-articular injection of a radionuclide [40] or total lymphoid irradiation [41].

\section{Radiotherapy Planning}

Megavoltage or orthovoltage radiotherapy machines may be utilized. The German Society for Radiooncology (Deutsche Gesellschaft für Radioonkologie [DEGRO]) recommends the target volumes for enthesopathies should encompass the complete involved insertion area including the nearby bony and muscular tissues. For painful arthroses, DEGRO recommends target volumes must include the articular cartilage, the nearby bony structures, the entire synovia, the surrounding muscles, and the periarticular connective tissues [25].

Appropriate fields to cover the target volume and provide a uniform dose distribution should be used. Large joints such as the shoulder and knee are treated with two opposed (anteroposterior/ posteroanterior) fields. While smaller joints of the hand can be treated with a single (direct) field [25].

In situations where the pain persists or the pain relief is insufficient 6-12 weeks post radiotherapy, a second series may be recommended $[25,42,43]$.

\section{Radiation Risk}

\section{Non-carcinogenic effect}

There are hardly any early or late effects of radiotherapy from LDRT. 
In the study by Niewald et al. [17], the only side effect was a mild redness of skin after radiotherapy (acute dermatitis) in one patient.

There are no accounts of relevant side effects due to anti-inflammatory radiotherapy to the knee in published literature [24]. In the study by Micke et al. [22] none of the 437 patients followed up for a median of 33 months developed any early or late effects.

\section{Radiation carcinogenesis}

It is established that X-ray irradiation has the potential to result in secondary cancers or radiation induced cancer. These secondary cancers include soft tissue sarcomas (usually malignant fibrous histiocytoma [MFH] and fibrosarcoma), thyroid cancer, colon cancer and leukemias $[31,44,45]$. This, in addition to accounts of radiation induced malignancies from survivors of the atomic bombs in Japan and other nuclear accidents, is what led to the worldwide decline in the use of radiotherapy as an option for the treatment of inflammatory/degenerative musculoskeletal conditions [17,31]. The first criteria for radiation induced sarcoma were established by $\mathrm{Ca}$ han et al. [46]. They include: (1) the sarcoma developed within the field or path of the radiation beam; (2) a 5-year latency period between the exposure to radiotherapy and the clinical appearance of the sarcoma; and (3) histologically confirmed diagnosis of the sarcoma. Arlen et al. [47] later modified the criteria to include the tissues adjacent to the path of the radiation beam also at risk for development of a sarcoma; and the latency period was reduced to 3-4 years.

Studies have shown that post-radiation sarcomas occur post exposure to a median dose of about $50 \mathrm{~Gy}$ (ranging from 8 Gy to over $60 \mathrm{~Gy}$ ) and a median latency period of 10 years (ranging from 2 years to up to 50 years) [48]. An estimate of $0.03 \%$ of patients who receive radiation to $0.2 \%$ of patients who have received radiation and survived 5 years later develop post-radiation sarcoma [48]. A study by Kuttesch et al. [49] noted no post-radiation sarcoma in patients receiving less than 48 Gy compared to an absolute risk of 130 cases per 10,000 person-years of patients who had received 60 Gy or more. Interestingly, it has been noted that persons exposed to low-dose radiation, such as survivors of atomic explosions do not report an increase in incidence of sarcoma $[50,51]$.

As early as 1990, a case report of a patient who was treated for ankylosing spondylitis at the age of 21 (1947/8) was published. He received a skin dose of $20 \mathrm{~Gy}$ in 10 fractions to the entire length of the vertebral column using a $200-k V p$ X-ray machine. In 1987, as a 61-year-old male patient, he presented with a history of upper thoracic pain which had been on for several years and a subcutaneous non-tender lesion at the upper thoracic paravertebral region. Histopathology of the resected tumor was revealed to be a leiomyosarcoma. However, this patient received $20 \mathrm{~Gy}$ of radiation therapy X-ray photons, far above the upper limit of the total dose to be received in LDRT (6 Gy) [44]. The authors also noted that, upon exposure to therapeutic single dose of ionizing radiation, an increase in death rate from cancers was noted. However, this increase did not reach statistical significance. In addition, excluding leukemia and colon cancers, the increased death rate peaked at 10-12 years post radiation exposure with peak persistence till 25 years [44].

LDRT for benign conditions including inflammatory/degenerative musculoskeletal conditions has been utilized in Germany since before the 1990's. And since then there has been considerable discussion and research into the risk of secondary cancers [31].

Radiation risks associated with LDRT are examples of stochastic effects. Stochastic effects are random statistical occurrences, the severity of the effect is not dependent on the dose of ionizing radiation, only the probability of the effect occurring is dose dependent, probably with no threshold [52]. To assess radiation risk, genetic and cancer risks need to be assessed. One needs to calculate the effective dose of radiation to estimate cancer risk. To do this coefficients and values published by the International Commission on Radiological Protection (ICRP) on the results of a reassessment of radiation risk they undertook in 2007 are used [27].

The effective dose estimates the tissue weighted sum of the equivalent doses in all specified tissues and organs of the body and is defined by the formula below:

$$
E=\sum_{T} W_{T} H_{T}=\sum_{T} W_{T} \sum_{R} W_{R} D_{T, R}
$$

where $E$ is the effective dose, $T$ is the tissue or organ of interest, $W_{T}$ is the tissue weighting factor (Table 2), $H_{T}$ is the equivalent dose absorbed by tissue $T, R$ is the radiation type, $W_{R}$ is the radiation weighting factor, $D_{T, R}$ is the mass-averaged absorbed dose in tissue $T$ by radiation type $R$ [27].

The unit of effective dose is Sievert. Each type of ionizing radiation has a weighting factor, for photons for example, the $W_{R}=1$. Each organ has its $W_{T}$ which further modifies the effective dose (Table 2). Each nation's nuclear regulatory agency factors in $W_{T}$ to arrive at national radiation protection policies and regulations [27].

\section{Genetic risk estimate}

The ICRP in 1991 estimated the probability of severe genetic damage in future generations to be $1 \% / \mathrm{Sv}$. The first and second generations risk are estimated at $0.15 \% / \mathrm{Sv}$, while the risk of the third and subsequent generations is $0.7 \% / S v[27,53]$. However, the 2007 estimates for genetic risks are much lower $[27,54]$. 
Table 1. Review of studies showing anti-inflammatory effect of low dose radiotherapy

\begin{tabular}{|c|c|c|c|c|c|c|}
\hline \multirow{2}{*}{ Author } & \multirow{2}{*}{$\begin{array}{l}\text { Study design } \\
\text { (sample size) }\end{array}$} & \multirow{2}{*}{ Disease condition } & \multirow{2}{*}{ Target site(s) } & \multirow{2}{*}{$\begin{array}{l}\text { Dose per fraction/ } \\
\text { total dose }\end{array}$} & \multicolumn{2}{|c|}{ Results } \\
\hline & & & & & Efficacy & Toxicity \\
\hline \multirow[t]{4}{*}{$\begin{array}{l}\text { Niewald et al. } \\
\text { [17] }\end{array}$} & \multirow[t]{4}{*}{$\begin{array}{l}\text { Retrospective obser- } \\
\text { vational }(n=141)\end{array}$} & \multirow[t]{4}{*}{ Periarthritis } & \multirow[t]{4}{*}{ Shoulder } & 1 Gy/6 Gy & $\begin{array}{l}\text { - Outcome: \% Pannewitz } \\
\text { class }\end{array}$ & $\begin{array}{l}\text { Mild hyperemia in } 1 \\
\text { patient }\end{array}$ \\
\hline & & & & Cobalt 60, $4 \mathrm{MV}$ and 6 & - Painless: 19\% & \\
\hline & & & & $\begin{array}{l}\text { MV LINAC, electrons, } \\
\text { orthovoltage }\end{array}$ & - Markedly improved: 39\% & \\
\hline & & & & & - Improved: $11 \%$ & \\
\hline \multirow[t]{3}{*}{$\begin{array}{l}\text { Micke et al. } \\
\text { [22] }\end{array}$} & \multirow[t]{3}{*}{$\begin{array}{l}\text { Prospective obser- } \\
\text { vational }(n=703)\end{array}$} & \multirow{3}{*}{$\begin{array}{l}\text { Calcaneodynia, } \\
\text { achillodynia, pain- } \\
\text { ful gonarthrosis, } \\
\text { painful bursitis } \\
\text { trochanterica, and } \\
\text { painful shoulder } \\
\text { syndrome }\end{array}$} & \multirow{3}{*}{ Various } & $\begin{array}{l}0.5 \mathrm{~Gy} / 6 \text { Gy or } 1 \mathrm{~Gy} / \\
6 \mathrm{~Gy}\end{array}$ & \multirow{3}{*}{$\begin{array}{l}\text { - Outcome: VAS and VPS } \\
\text { - All patients: median VAS } \\
\text { before RT-7.0, after RT- } \\
4.5, p<0.001 \\
\text { - } \% \text { good response by VPS } \\
\text { on completion of RT- } \\
37.6 \% \text {, on follow-up } \\
58.4 \%, p<0.001\end{array}$} & \multirow{3}{*}{$\begin{array}{l}\text { No side effects ob- } \\
\text { served }\end{array}$} \\
\hline & & & & LINAC and orthovoltage & & \\
\hline & & & & & & \\
\hline \multirow[t]{5}{*}{$\begin{array}{l}\text { Hautmann et al } \\
\text { [24] }\end{array}$} & \multirow[t]{5}{*}{$\begin{array}{l}\text { Prospective obser- } \\
\text { vational }(n=20)\end{array}$} & \multirow[t]{5}{*}{ Baker's cyst } & \multirow[t]{5}{*}{ Knee } & $\begin{array}{l}0.5 \mathrm{~Gy} / 3 \mathrm{~Gy} \text { or } 1 \mathrm{Gyl} \\
6 \mathrm{~Gy}\end{array}$ & \multicolumn{2}{|c|}{$\begin{array}{l}\text { - Outcome: NRS, KSS, cyst No acute or long- } \\
\text { volume } \\
\text { term side effects }\end{array}$} \\
\hline & & & & $6 \mathrm{MV}$ or $15 \mathrm{MV}$ LINAC & \multicolumn{2}{|l|}{$\begin{array}{l}\text { - Median NRS at base- } \\
\text { line-6.5, on short-term } \\
\text { follow-up-3, on long- } \\
\text { term follow-up-2; gen- } \\
\text { eral response (NRS) on } \\
\text { short-term follow-up } \\
72 \%(p<0.005) \text { on } \\
\text { long-term follow-up } \\
60 \%(p=0.05)\end{array}$} \\
\hline & & & & & \multicolumn{2}{|l|}{$\begin{array}{l}\text { - Median KSS at base- } \\
\text { line-49, on short-term } \\
\text { follow-up-65, on long- } \\
\text { term follow-up-70; } \\
\text { general response (KSS) } \\
\text { on short-term fol- } \\
\text { low-up } 67 \% \text { ( } p<0.008) \text {, } \\
\text { on long-term follow-up } \\
67 \%(p=0.068)\end{array}$} \\
\hline & & & & & \multirow{2}{*}{\multicolumn{2}{|c|}{$\begin{array}{l}\text { - Mean cyst volume (mL) } \\
\text { at baseline-22.3, on } \\
\text { short-term follow-up } \\
\text {-10.7, on long-term } \\
\text { follow-up -3.1; general } \\
\text { response (cyst volume) } \\
\text { on short-term fol- } \\
\text { low-up 75\% } \\
\text { ( } p=0.0020 \text {, on long- } \\
\text { term follow-up 79\% } \\
\text { ( } p=0.003) \\
\text { - Other outcomes tested } \\
\text { was WOMAC score }\end{array}$}} \\
\hline & & & & & & \\
\hline \multirow[t]{4}{*}{$\begin{array}{l}\text { Kaltenborn et a } \\
\text { [38] }\end{array}$} & \multirow[t]{4}{*}{$\begin{array}{l}\text { Retrospective obser- } \\
\text { vational }(n=84)\end{array}$} & \multirow[t]{4}{*}{ Osteoarthritis } & \multirow[t]{4}{*}{$\begin{array}{l}\text { Thumb (car- } \\
\text { pometacar- } \\
\text { pal joint) }\end{array}$} & \multirow[t]{4}{*}{1 Gy/6 Gy 6 MV LINAC } & $\begin{array}{l}\text { - Outcome: subjective, } \\
\text { patient reported re- } \\
\text { sponse; response = } \\
\text { complete response + } \\
\text { partial response }\end{array}$ & \multirow[t]{4}{*}{ Unknown } \\
\hline & & & & & $\begin{array}{l}\text { - \% response at the end } \\
\text { of therapy, } 70 \%\end{array}$ & \\
\hline & & & & & $\begin{array}{l}\text { - } \% \text { response at } 3 \text { months } \\
\text { post therapy, } 60 \%\end{array}$ & \\
\hline & & & & & $\begin{array}{l}\text { - } \% \text { response at 1-year } \\
\text { post-therapy, } 70 \%\end{array}$ & \\
\hline
\end{tabular}


Table 1. Continued

\begin{tabular}{|c|c|c|c|c|c|c|}
\hline \multirow{2}{*}{ Author } & \multirow{2}{*}{$\begin{array}{l}\text { Study design } \\
\text { (sample size) }\end{array}$} & \multirow{2}{*}{ Disease condition } & \multirow{2}{*}{ Target site(s) } & \multirow{2}{*}{$\begin{array}{l}\text { Dose per fraction/ } \\
\text { total dose }\end{array}$} & \multicolumn{2}{|l|}{ Results } \\
\hline & & & & & Efficacy & Toxicity \\
\hline \multirow{3}{*}{$\begin{array}{l}\text { Graninger et al. } \\
\text { [39] }\end{array}$} & \multirow{3}{*}{$\begin{array}{l}\text { Randomised con- } \\
\text { trolled double } \\
\text { blind stud }(n=6)\end{array}$} & \multirow{3}{*}{$\begin{array}{l}\text { Rheumatoid arthri- } \\
\text { tis }\end{array}$} & \multirow{3}{*}{ Varying joints } & 2 Gy/20 Gy & \multirow{3}{*}{$\begin{array}{l}\text { - Outcome: joint tender- } \\
\text { ness and swelling ex- } \\
\text { pressed on a } 0 \text { to } 3 \text { or- } \\
\text { dinal scale. } \\
\text { - No therapeutic effect } \\
\text { noted when irradiation } \\
\text { was compared to sham } \\
\text { (placebo). }\end{array}$} & \multirow{3}{*}{ Unknown } \\
\hline & & & & $20 \mathrm{MeV}$ LINAC & & \\
\hline & & & & & & \\
\hline \multirow[t]{3}{*}{$\begin{array}{l}\text { Ott et al. } \\
\text { [43] }\end{array}$} & \multirow{3}{*}{$\begin{array}{l}\text { Prospective ran- } \\
\text { domized trial } \\
(n=199)\end{array}$} & \multirow[t]{3}{*}{$\begin{array}{l}\text { Benign painful el- } \\
\text { bow syndrome }\end{array}$} & \multirow[t]{3}{*}{ Elbow } & $\begin{array}{c}0.5 \mathrm{~Gy} / 3 \mathrm{~Gy} \text { or } 1 \mathrm{~Gy} / \\
6 \mathrm{~Gy} \text { orthovoltage }\end{array}$ & \multirow{3}{*}{$\begin{array}{l}\text { - Outcome: VAS and com- } \\
\text { prehensive pain score } \\
\text { - Overall response rate di- } \\
\text { rectly after radiothera- } \\
\text { py }-80 \%, 6 \text { weeks after } \\
-91 \%, 3 \text { years after } \\
-94 \% \text {. } \\
\text { - No significant difference } \\
\text { in outcomes between } \\
\text { the } 0.5 \text { Gy and } 1 \text { Gy per } \\
\text { fraction regimens. }\end{array}$} & \multirow{3}{*}{$\begin{array}{l}\text { No side effects ob- } \\
\text { served }\end{array}$} \\
\hline & & & & & & \\
\hline & & & & & & \\
\hline \multirow[t]{5}{*}{$\begin{array}{l}\text { Gross et al. } \\
\text { [64] }\end{array}$} & \multirow{5}{*}{$\begin{array}{l}\text { Prospective ran- } \\
\text { domized study } \\
\text { (n=30; } 14 \text { RT vs. } \\
16 \text { ESWT) }\end{array}$} & \multirow[t]{5}{*}{$\begin{array}{l}\text { Supraspinatus ten- } \\
\text { don syndrome }\end{array}$} & \multirow[t]{5}{*}{ Shoulder } & $\begin{array}{l}\text { RT: } 0.5 \text { Gy/3 Gy Cobalt } \\
\quad-60\end{array}$ & \multirow{2}{*}{$\begin{array}{l}\text { - Outcome: Age corrected } \\
\text { constant score and side } \\
\text { effects were compared } \\
\text { between RT and ESWT. }\end{array}$} & \multirow{5}{*}{$\begin{array}{l}\text { No acute side ef- } \\
\text { fects occurred due } \\
\text { to RT } \\
\text { : }\end{array}$} \\
\hline & & & & vs. ESWT 2000 pulse $3 X$ & & \\
\hline & & & & & $\begin{array}{l}\text { - In average RT group age } \\
\text { corrected constant score } \\
\text { improved from } 47.6 \\
\text { points before treatment } \\
\text { through } 79.5 \text { points af- } \\
\text { ter } 12 \text { weeks to } 87.4 \\
\text { points after } 52 \text { weeks. }\end{array}$ & \\
\hline & & & & & $\begin{array}{l}\text { - In ESWT average age } \\
\text { corrected constant score } \\
\text { improved from } 50.1 \\
\text { points before treatment } \\
\text { through } 91.4 \text { points af- } \\
\text { ter } 12 \text { weeks to } 97.8 \\
\text { points after } 52 \text { weeks. }\end{array}$ & \\
\hline & & & & & $\begin{array}{l}\text { - No acute side effects } \\
\text { due to RT were observed. } \\
\text { One patient had pain } \\
\text { and one had moderate } \\
\text { skin irritation after } \\
\text { ESWT. }\end{array}$ & \\
\hline \multirow{2}{*}{$\begin{array}{l}\text { Keinert et al. } \\
\text { [66] }\end{array}$} & \multirow{2}{*}{$\begin{array}{l}\text { Retrospective obser- } \\
\text { vational; no con- } \\
\text { trol group } \\
(\mathrm{n}=290)\end{array}$} & \multirow{2}{*}{ Osteoarthritis } & \multirow[t]{2}{*}{ Knee } & \multirow{2}{*}{$\begin{array}{l}0.5 \mathrm{~Gy} / 3-4 \mathrm{~Gy} \text { or } \\
1 \mathrm{~Gy} / 6-8 \mathrm{~Gy}\end{array}$} & - Outcome: pain & \multirow[t]{2}{*}{ Unreported } \\
\hline & & & & & $\begin{array}{l}\text {-64\% were free of pain } \\
\text { or had improved pain } \\
\text { immediately after } \\
\text { treatment, and } 81 \% 6 \\
\text { weeks after treatment. }\end{array}$ & \\
\hline \multirow{2}{*}{$\begin{array}{l}\text { Keller et al. } \\
\text { [67] }\end{array}$} & \multirow{2}{*}{$\begin{array}{l}\text { Retrospective obser- } \\
\text { vational; no con- } \\
\text { trol group } \\
(n=1,037)\end{array}$} & \multirow{2}{*}{ Osteoarthritis } & \multirow[t]{2}{*}{ Knee } & \multirow[t]{2}{*}{ 0.5-1 Gy/4-6 Gy } & - Outcome: pain & \multirow[b]{2}{*}{ Unreported } \\
\hline & & & & & $\begin{array}{l}\text { - Immediately or up to } 2 \\
\text { months post treatment } \\
79.3 \% \text { of patients ex- } \\
\text { perienced a slight, } \\
\text { marked or complete } \\
\text { pain relief. } \\
\text { 2-14 years after thera- } \\
\text { py, } 49.1 \text { still experi- } \\
\text { enced a slight, marked } \\
\text { or complete pain relief. }\end{array}$ & \\
\hline
\end{tabular}

VAS, visual analogue score; VPS, four-scale pain score according to von Pannewitz; RT, radiotherapy; LINAC, linear accelerator; NRS, numeric rating score; KSS, Knee Society Score; WOMAC, Western Ontario and McMaster Universities Osteoarthritis Index; ESWT, extracorporeal shock wave therapy. 
Table 2. Tissue weighting factors according to ICRP 103 (ICRP 2007)

\begin{tabular}{lcc}
\hline Tissue $(T)$ & Tissue weighting factor $\left(w_{T}\right)$ & $\sum w_{T}$ \\
\hline Bone marrow (red), colon, lung, stomach, breast & 0.12 & 0.72 \\
Gonads & 0.08 & 0.08 \\
Bladder, esophagus, liver, thyroid & 0.04 & 0.16 \\
Bone surface, brain, salivary glands, skin & 0.01 & 0.04 \\
Remaining tissues $(\mathrm{n}=13)^{\text {a) }}$ & 0.0092 & 0.12 \\
Total & - & 1.00 \\
\hline
\end{tabular}

ICRP, International Commission on Radiological Protection.

a) Remaining tissues: adrenals, extrathoracic region, gall bladder, heart, kidneys, lymphatic nodes, muscle, oral mucosa, pancreas, prostate (male), small intestine, spleen, thymus, uterus/cervix (female).

\section{Cancer risk estimate}

It is established that ionizing radiation exposure can result in secondary malignancy. However, the controversy is in the mathematical models to estimate this risk. The ICRP estimates the incidence of cancer from exposure to ionizing radiation to be 5.5\%/Sv [54]. The ICRP's model for radiation safety utilizes the effective dose, doses and dose rate effectiveness factor (DDREF) which obtains a value of 2 in doses utilized in LDRT, and the proportion of the irradiated region to the total body weight [27]. From this a middle-aged man irradiated with 6 Gy in 6 fractions at 1 Gy per fraction to the knee is estimated to have received an effective dose of $0.038 \mathrm{~Sv}$ (38 mSv) [54]. The effective dose of a computed tomography (CT) scan to the abdomen ranges up to $20 \mathrm{mSv}$ [27]. Going by the ICRP estimate, this irradiation thus increases the lifetime cancer risk by about $0.038 \mathrm{~Sv} \times 5.5 \mathrm{~Sv}^{-1}=0.2 \%$ [27].

In spite of this low risk as estimated by the ICRP, certain researchers, groups and bodies claim the ICRP's model, which is mainly for whole body exposures to members of the public and occupational exposures, overestimates the true risk of radiation induced cancer for therapeutic radiation.

According to Trott and Kamprad [21], the effective dose method employed by the ICRP to estimate the risk of ionizing radiation exposure to the general population was not adequate when applied to estimating the risk of therapeutic radiation for benign or malignant conditions [55]. This is based on the fact that the types of cancer induced by therapeutic radiation differ from those induced by low dose total body irradiation to the population as in the case of Japanese atomic bombs survivors [31]. They also claim that radiotherapy induced malignancies do not follow the same linear non-threshold (LNT) model used in radiation protection risk assessment. They further state that the LNT model overestimates the true risk of therapeutic radiation induced cancer by one order of magnitude. In addition, these researchers note that the risk of cancer induction from LDRT should rather be based on epidemiologic data of patients who have received such treatment in the past [31].

According to Ottolenghi et al. [56], the most significant factor regarding cancer risk is the anatomical site of treatment. They noted that treatment of conditions in the appendages of the human body such as Dupuytren's contracture, tennis elbow or heel spur result in a very low cancer risk estimated to be similar to that due to a common diagnostic radiologic procedure. However, the major risk in radiotherapy for benign conditions involving the axial skeleton, which has significant amount of red bone marrow, is leukemia. As such the treatment of these locations should take account of and reduce the mean bone marrow dose [56]. In spite of this leukemia risk, a paper by Cuttler [57] suggests a relatively high threshold dose of $500 \mathrm{mSv}$ for ionizing radiation induced leukemia in humans. Sautter-Bihl et al. [58] used the LNT model to provide a quantitative estimate of cancer risk based on LDRT for treatment of inflammatory joint conditions. To arrive at their estimation, they accounted for factors such as the expected average exposures (assumed to be 6 Gy in 6 fractions at 1 dose per fraction) and differential distance to irradiated areas. They also extrapolated the dose to a whole body dose using an established whole body conversion formula. They thus estimated LDRT for benign inflammatory musculoskeletal conditions to result in additional 20-40 malignancies per million people over a lifetime. They went further to note that the average age of patients receiving LDRT for inflammatory joint disorders was 54 years. They thus argued that the cancer risk for this procedure is of no practical relevance.

In another study into radiation carcinogenesis, a mathematical model estimated at total dose of $6 \mathrm{~Gy}$ for $\mathrm{OA}$ of the knee relates to an effective dose of $13 \mathrm{mSv}$, which compares to the effective doses from an abdominopelvic CT scan [59]. The authors of the study further estimated the average attributable life time risk for an induced fatal tumor to be about 0.7 in a thousand patients treated at the age of 50 years. However, the risk further reduces to 0.3 in a thousand patients once treated at the age of 70 years [60].

It should be noted that in less peripheral lesions the risk of radiation induced cancers increases. This is due to the exposure to more sensitive organs such as the red bone marrow and the gastrointestinal tract [16]. 
In Germany, in spite of these known low estimates of radiation induced cancer, there are established protocols to further reduce the risk. LDRT for inflammatory/degenerative musculoskeletal disorders is only done when standard non-radiation treatments have failed. In addition, patients under the age of 40 years are only treated in exceptional circumstances and even then not until all the possible risk and benefits of the procedures have been determined [23].

Having addressed the risk of LDRT for inflammatory/degenerative musculoskeletal disorders it should be noted that the other modalities of treatment are not without side effects or complications. The complications of surgery and anesthesia are known. Intrathecal steroid injection could result in infections, necrosis, tendon rupture and side effects due to the systemic effects of steroids [17,61]. One widely accepted modality for treating these conditions is stem cell transplantation. The side effects of this include graft versus host disease, susceptibility to infection and non-malignant organ or tissue dysfunction [62]. Extracorporeal shock wave therapy (ESWT) is associated with effects which are not limited to transitory reddening of the skin, pain, small hematomas, migraine and syncope [63]. Moreover, a randomized trial comparing ESWT to LDRT found both to be of equal efficacy $[64,65]$.

\section{Conclusion}

Literature showed that many countries in Europe, especially Germany use radiation routinely for the treatment of many degenerative disorders including osteoarthritis with good results and few side effects. With LDRT for OA of the knee resulting in an effective dose equivalent to an abdominopelvic CT scan. Considering how recalcitrant to treatment degenerative skeletal conditions can be, LDRT is proven to be a reasonable and acceptable treatment option. A pilot study is therefore recommended with a view to establish the effectiveness or otherwise of this treatment method in regions of the world that have not adopted it.

\section{Conflict of Interest}

No potential conflict of interest relevant to this article was reported.

\section{References}

1. The Lancet. Managing arthritis in the USA. Lancet 2017;389: 1076.

2. O'Donnell S, Lagace $C$, McRae $L$, Bancej $C$. Life with arthritis in
Canada: a personal and public health challenge. Chronic Dis Inj Can 2011;31:135-6.

3. GBD 2010 Country Collaboration. GBD 2010 country results: a global public good. Lancet 2013;381:965-70.

4. Australian Orthopaedic Association. Hip and knee Arthroscopy (National Joint Replacement Registry Annual Report 2009) [Internet]. Sydney, Australia: Australian Orthopaedic Association; 2009 [cited 2020 Jun 5]. Available from: https://aoanjrr.sahmri. com/documents/10180/42728/Annual+Report+2009.

5. Usenbo A, Kramer V, Young T, Musekiwa A. Prevalence of arthritis in Africa: a systematic review and meta-analysis. PLoS One 2015;10:e0133858.

6. Fransen M, Bridgett L, March L, Hoy D, Penserga E, Brooks P. The epidemiology of osteoarthritis in Asia. Int J Rheum Dis 2011; 14:113-21.

7. Park J, Mendy A, Vieira ER. Various types of arthritis in the United States: prevalence and age-related trends from 1999 to 2014. Am J Public Health 2018;108:256-8.

8. Lozano R, Naghavi M, Foreman $K_{1}$ et al. Global and regional mortality from 235 causes of death for 20 age groups in 1990 and 2010: a systematic analysis for the Global Burden of Disease Study 2010. Lancet 2012;380:2095-128.

9. Cross M, Smith $E_{1}$ Hoy D, et al. The global burden of rheumatoid arthritis: estimates from the global burden of disease 2010 study. Ann Rheum Dis 2014;73:1316-22.

10. Zeng XF, Zhu SL, Tan AC, Xie XP. Disease burden and quality of life of rheumatoid arthritis in China: a systematic review. Chin J Evid Based Med 2013;13:300-7.

11. Dargham SR, Zahirovic S, Hammoudeh $M$, et al. Epidemiology and treatment patterns of rheumatoid arthritis in a large cohort of Arab patients. PLoS One 2018;13:e0208240.

12. Alamanos Y, Drosos AA. Epidemiology of adult rheumatoid arthritis. Autoimmun Rev 2005;4:130-6.

13. Humphreys JH, Verstappen SM, Hyrich KL, Chipping JR, Marshall T, Symmons DP. The incidence of rheumatoid arthritis in the UK: comparisons using the 2010 ACR/EULAR classification criteria and the 1987 ACR classification criteria: results from the Norfolk Arthritis Register. Ann Rheum Dis 2013;72:1315-20.

14. Hunter TM, Boytsov NN, Zhang X, Schroeder K, Michaud K, Araujo $A B$. Prevalence of rheumatoid arthritis in the United States adult population in healthcare claims databases, 2004-2014. Rheumatol Int 2017;37:1551-7.

15. Serber W, Dzeda MF, Hoppe RT. Radiation treatment of benign disease. In : Perez CA, Brady LW, editors. Principles and practice of radiation oncology. 3rd ed. Philadelphia, PA: Lippincott Williams \& Wilkins; 1998, p. 2167-85.

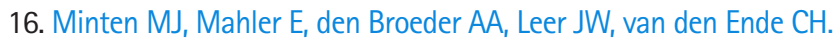


The efficacy and safety of low-dose radiotherapy on pain and functioning in patients with osteoarthritis: a systematic review. Rheumatol Int 2016;36:133-42.

17. Niewald M, Fleckenstein J, Naumann S, Ruebe C. Long-term results of radiotherapy for periarthritis of the shoulder: a retrospective evaluation. Radiat Oncol 2007;2:34.

18. Hill L, Windeyer BW. Discussion on the place of radiotherapy in the treatment of the arthritic joint. Proc R Soc Med 1952;45: 543-8.

19. Anders JM, Daland J, Pfahler GF. The treatment of arthritis deformans with the roentgen rays: a preliminary report. JAMA 1906;46:1512-4.

20. Muscoplat CC, Caperton EM, Dusenbery KE. Radiation therapy for inflammatory arthritis. Int J Radiat Oncol Biol Phys 2004;60:6889.

21. Trott KR, Kamprad F. Radiobiological mechanisms of anti-inflammatory radiotherapy. Radiother Oncol 1999;51:197-203.

22. Micke O, Ugrak E, Bartmann S, et al. Radiotherapy for calcaneodynia, achillodynia, painful gonarthrosis, bursitis trochanterica, and painful shoulder syndrome: early and late results of a prospective clinical quality assessment. Radiat Oncol 2018;13:71.

23. Seegenschmiedt MH, Micke O, Willich N. Radiation therapy for nonmalignant diseases in Germany: current concepts and future perspectives. Strahlenther Onkol 2004;180:718-30.

24. Hautmann MG, Jung EM, Beyer LP, et al. Is low dose radiotherapy an effective treatment for Baker's cyst? Strahlenther Onkol 2019;195:69-76.

25. Ott OJ, Niewald M, Weitmann HD, et al. DEGRO guidelines for the radiotherapy of non-malignant disorders. Part II: Painful degenerative skeletal disorders. Strahlenther Onkol 2015;191:1-6.

26. Forster C, Keilholz L, Kern P, Kalden JR, Sauer R. Modulation endothelabhängiger Adhäsion durch anti-inflammatorische Bestrahlung mit niedriger Dosis [abstract]. Strahlenther Onkol 1997;173:623.

27. Reichl B, Block A, Schafer U, et al. DEGRO practical guidelines for radiotherapy of non-malignant disorders: part I: physical principles, radiobiological mechanisms, and radiogenic risk. Strahlenther Onkol 2015;191:701-9.

28. Roedel F, Kley N, Beuscher HU, et al. Anti-inflammatory effect of low-dose X-irradiation and the involvement of a TGF-beta1-induced down-regulation of leukocyte/endothelial cell adhesion. Int J Radiat Biol 2002;78:711-9.

29. Arenas M, Gil F, Gironella M, et al. Anti-inflammatory effects of low-dose radiotherapy in an experimental model of systemic inflammation in mice. Int J Radiat Oncol Biol Phys 2006;66:560-7.

30. Lodermann $B$, Wunderlich $R$, Frey $S$, et al. Low dose ionising radiation leads to a NF-kB dependent decreased secretion of active
IL-1 $\beta$ by activated macrophages with a discontinuous dose-dependency. Int J Radiat Biol 2012;88:727-34.

31. Calabrese EJ, Dhawan G, Kapoor R, Kozumbo WJ. Radiotherapy treatment of human inflammatory diseases and conditions: optimal dose. Hum Exp Toxicol 2019;38:888-98.

32. von Pannewitz G. Radiotherapy of arthrosis deformans: method and results. Radiologe 1970;10:51-4.

33. Trott KR, Parker $R$, Seed MP. The effect of X-rays on experimental arthritis in the rat. Strahlenther Onkol 1995;171:534-8.

34. Fischer U, Kamprad F, Koch F, Ludewig E, Melzer R, Hildebrandt G. The effects of low-dose Co-60 irradiation on the course of aseptic arthritis in a rabbit knee joint. Strahlenther Onkol 1998;174: 633-9.

35. Hildebrandt G, Seed MP, Freemantle CN, Alam CA, Colville-Nash $P R$, Trott KR. Effects of low dose ionizing radiation on murine chronic granulomatous tissue. Strahlenther Onkol 1998;174: 580-8.

36. Hildebrandt G, Radlingmayr A, Rosenthal $S$, et al. Low-dose radiotherapy (LD-RT) and the modulation of iNOS expression in adjuvant-induced arthritis in rats. Int J Radiat Biol 2003;79:9931001.

37. Hildebrandt $G$, Jahns J, Hindemith $M$, et al. Effects of low dose radiation therapy on adjuvant induced arthritis in rats. Int J Radiat Biol 2000;76:1143-53.

38. Kaltenborn A, Bulling E, Nitsche M, Carl UM, Hermann RM. The field size matters: low dose external beam radiotherapy for thumb carpometacarpal osteoarthritis: importance of field size. Strahlenther Onkol 2016;192:582-8.

39. Graninger M, Handl-Zeller L, Hohenberg G, Staudenherz A, Kainberger F, Graninger W. Teleradiotherapy of joints in rheumatoid arthritis: lack of efficacy. Ann Rheum Dis 2005;64:138-40.

40. Ahmad I, Nisar H. Dosimetry perspectives in radiation synovectomy. Phys Med 2018;47:64-72.

41. Herbst M, Fritz H, Sauer R. Total lymphoid irradiation of intractable rheumatoid arthritis. Br J Radiol 1986;59:1203-7.

42. Ott OJ, Hertel S, Gaipl US, Frey B, Schmidt M, Fietkau R. Benign painful elbow syndrome: first results of a single center prospective randomized radiotherapy dose optimization trial. Strahlenther Onkol 2012;188:873-7.

43. Ott OJ, Hertel S, Gaipl US, Frey B, Schmidt M, Fietkau R. The Erlangen Dose Optimization Trial for low-dose radiotherapy of benign painful elbow syndrome: long-term results. Strahlenther Onkol 2014;190:293-7.

44. Stevens GN, Tattersall MH, Stalley P. Leiomyosarcoma following therapeutic irradiation for ankylosing spondylitis. Br J Radiol 1990;63:730-2.

45. Mahmood S, Vu K, Tai P, et al. Radiation-induced second malig- 
nancies. Anticancer Res 2015;35:2431-4.

46. Cahan WG, Woodard HQ, Higinbotham NL, Stewart FW, Coley BL. Sarcoma arising in irradiated bone: report of eleven cases. 1948. Cancer 1998;82:8-34.

47. Arlen M, Higinbotham NL, Huvos AG, Marcove RC, Miller T, Shah IC. Radiation-induced sarcoma of bone. Cancer 1971;28:108799.

48. Patel SR. Radiation-induced sarcoma. Curr Treat Options Oncol 2000;1:258-61.

49. Kuttesch JF Jr, Wexler LH, Marcus RB, et al. Second malignancies after Ewing's sarcoma: radiation dose-dependency of secondary sarcomas. J Clin Oncol 1996;14:2818-25.

50. Haselow RE, Nesbit M, Dehner LP, Khan FM, McHugh R, Levitt SH. Second neoplasms following megavoltage radiation in a pediatric population. Cancer 1978;42:1185-91.

51. Pinkston JA, Wakabayashi T, Yamamoto $T$, et al. Cancer of the head and neck in atomic bomb survivors: Hiroshima and Nagasaki, 1957-1976. Cancer 1981;48:2172-8.

52. Hall EJ, Giaccia AJ. Radiobiology for the Radiologist 6th ed. Philadelphia, PA: Lippincott Williams \& Wilkins; 2006.

53. International Commission on Radiological Protection. 1990 Recommendations of the International Commission on Radiological Protection (ICRP Publication 60). Stockholm, Sweden: International Commission on Radiological Protection; 1991.

54. The 2007 Recommendations of the International Commission on Radiological Protection. ICRP publication 103. Ann ICRP 2007; 37:1-332.

55. Trott KR, Kamprad F. Estimation of cancer risks from radiotherapy of benign diseases. Strahlenther Onkol 2006;182:431-6.

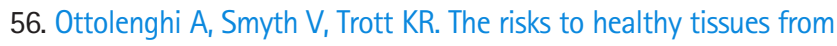
the use of existing and emerging techniques for radiation therapy. Radiat Prot Dosimetry 2011;143:533-5.

57. Cuttler JM. Evidence of a dose threshold for radiation-induced leukemia. Dose Response 2018;16:1559325818811537.
58. Sautter-Bihl ML, Liebermeister E, Scheurig H, Heinze HG. Analgetic irradiation of degenerative-inflammatory skeletal diseases: benefits and risks. Dtsch Med Wochenschr 1993;118:493-8.

59. Smith-Bindman R, Lipson J, Marcus R, et al. Radiation dose associated with common computed tomography examinations and the associated lifetime attributable risk of cancer. Arch Intern Med 2009;169:2078-86.

60. Jansen JT, Broerse JJ, Zoetelief J, Klein C, Seegenschmiedt HM. Estimation of the carcinogenic risk of radiotherapy of benign diseases from shoulder to heel. Radiother Oncol 2005;76:270-7.

61. Grillet B, Dequeker J. Intra-articular steroid injection: a risk-benefit assessment. Drug Saf 1990;5:205-11.

62. Mohty B, Mohty M. Long-term complications and side effects after allogeneic hematopoietic stem cell transplantation: an update. Blood Cancer J 2011;1:e16.

63. Haake M, Boddeker IR, Decker T, et al. Side-effects of extracorporeal shock wave therapy (ESWT) in the treatment of tennis elbow. Arch Orthop Trauma Surg 2002;122:222-8.

64. Gross MW, Sattler $A_{1}$ Haake $M$, et al. The effectiveness of radiation treatment in comparison with extracorporeal shockwave therapy (ESWT) in supraspinatus tendon syndrome. Strahlenther Onkol 2002;178:314-20.

65. Haake M, Sattler A, Gross MW, Schmitt J, Hildebrandt R, Muller $\mathrm{HH}$. Comparison of extracorporeal shockwave therapy (ESWT) with roentgen irradiation in supraspinatus tendon syndrome: a prospective randomized single-blind parallel group comparison. Z Orthop Ihre Grenzgeb 2001;139:397-402.

66. Keinert K, Schalldach U, Schumann E. Results of irradiation therapy of arthrosis deformans of the knee-joint. Dtsch Gesundheitsw Z Klin 1982;37:445-7.

67. Keller S, Muller K, Kortmann RD, et al. Efficacy of low-dose radiotherapy in painful gonarthritis: experiences from a retrospective East German bicenter study. Radiat Oncol 2013;8:29. 